\title{
Development of Family-based Narcotics Abuse Model Rehabilitation among Adolescents with EVIE Method in DKI Jakarta in 2017-2019
}

\author{
Andi Julia Rifiana ${ }^{1}$, Afrizal Afrizal $^{2}$, Rizanda Machmud ${ }^{2}$, Adnil Edwin $^{2}$, Anwar Mallongi $^{3 *}$ \\ ${ }^{1}$ Student of Doctoral Degree Program, Andalas University, Padang, Indonesia; ${ }^{2}$ Faculty of Medicine, Andalas University, \\ Padang, Indonesia; ${ }^{3}$ Department of Environmental Health, Faculty of Public Health, Makassar, Indonesia
}

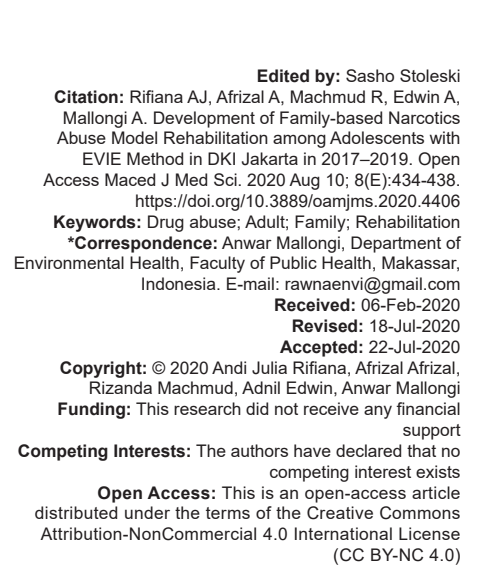

(CC BY-NC 4.0)

\begin{abstract}
BACKGROUND: The results of a national survey conducted by the National Narcotics Agency (BNN) in collaboration with the Center for Research on Pranata, University of Indonesia, showed the prevalence of drug-psychotropic abuse among junior, high school, and tertiary students in 30 provincial capitals in 2013 by $3.4 \%$. Trends in the number of abusers among adolescents show an increase every year. Until 2013, the number of drug abusers among adolescents increased $\times 3$ from 2009 .

AIM: This study was conducted to determine the direct and indirect factors affecting drug abuse in teenage

MATERIALS AND METHODS: The study used a mix method qualitative and quantitative study methods through univariate analysis. The study population consisted of family and teen's drug abuser, and a sample of 40 of them was taken.

RESULTS: The measurement results of univariate analysis statistics on the influence of variables in the structura model, and overall variables showed a positive and significant effect. The T-statistic value of all variables was above the critical value (1.96). The results of the test indicated that the empowerment and social support variables, directly and indirectly, and influenced factors abilities. Knowledge, perceptions, attitudes, and parenting had impacts directly on the factors abilities. Knowledge, family support, perceptions, attitudes, and parenting variables had an influence on the drug abuse abilities of teen.
\end{abstract}

CONCLUSION: A controlled trial study should be done to see the impact of this model on reducing the risks during rehabilitation.

\section{Introduction}

In Indonesia, narcotics have become a social problem. Based on the results of BNN research in collaboration with the Indonesian Center for Research and Health in 2011, that the prevalence of drug abusers in Indonesia has reached $2.23 \%$ or about 4.2 million people from the total population (aged 10-59 years). In 2015, the number of drug abusers was \pm $2.8 \%$ or equivalent to $\pm 5.1-5.6$ million people from the Indonesian population [1]. The results of a national survey conducted by the National Narcotics Agency (BNN), in collaboration with the Center for Research on Pranata, University of Indonesia, showed the prevalence of drug-psychotropic abuse among junior, high school, and tertiary students in 30 provincial capitals in 2013 by $3.4 \%$. Trends in the number of abusers among adolescents show an increase every year. Until 2013, the number of drug abusers among adolescents increased $\times 3$ from 2009 . This is due to teenagers who still have unstable souls and are still in the stage of searching for their identity so that this is very possible easily contaminated with drugs.
Of course, this is greatly influenced by weak control, especially by the family.

The data show the extent and depth of drug cases. The extent is marked by a large number reaching 43,767 cases, while the depth of drug trafficking does not distinguish between sex, age, education, and occupational background. The drug suspects include children, those who are $<16$ years old. Through various studies, strong evidence is found that the number of drug users is closely related to the increase in criminal acts [2].

The rehabilitation of drug users so far is conventional. By giving medicines, caring for the hospital, and organizing physical and psychological activities that are beneficial for the mental healing of the patient. The patient is placed in a special hospital or Drug Addiction Hospital (RSKO). Such methods did not provide adequate results because the recovery rate was very small. Out of 100 adolescent sufferers, the average cure rate is $<20 \%$ [3]. There is an important issue that is ignored, namely, the separation of sufferers from family (parents and siblings). Yet in mental healing, the family plays an important role. Families who understand the child's mental condition best because this is where 
children are educated and raised and will also return to the family [4]. Therefore, it is necessary to do integration between sufferers and families.

The family plays an important role in the process of physical and psychological growth of a person. In the process of one's growth, adolescence is an important period because this time, someone usually experiences a crisis. The crisis occurred because the process of maturity entered a stage where a person would interact more with peers (peer groups) than household members. The process of finding and forming an identity begins. The role of the family begins to decline while the role of institutions outside the family begins to strengthen. Symptoms like this take place in all family systems, both conjugal, conjunctival [5], as well as the nuclear family and extended family types.

\section{Materials and Methods}

This research is a quantitative study using a non-experimental method with a cross-sectional design. This research is to detect and look for a description of the characteristics of adolescent drug abusers who will be used to determine the indicators that will be used to look for problems so that adolescents can abuse drugs. Quantitative analysis will use SPSS so that it can determine what factors are in adolescent drug abusers.

This research was conducted in the working area of Tebet Subdistrict Puskesmas and Kramat Jati Sub-district in East Jakarta in 2018. This research is a census of drug abusers between the ages of 16 and 24 years (teenagers) with a random sampling technique. Data collection uses questionnaires and direct interviews with adolescent drug abusers. The questionnaire was prepared through validity and reliability tests with variables of education, knowledge, attitudes, perceptions, and parenting.

\section{Results}

Univariate analysis conducted aims to determine the frequency distribution of each variable studied.

Table 1 shows that the behavior of parents in the rehabilitation of adolescent drug abuse among adolescents in DKI Jakarta is more than half less categorized $(60 \%)$. Based on the age category of the parents, $51.5 \%$ belong to the category of young adults aged 20-40 years. Based on the level of education, the majority of respondents are highly educated ( $\geq$ spinal muscular atrophy), with $75.2 \%$ of respondents. Based on the work, the majority of respondents (mothers) work outside the home in the sense that the mother also helps the family economy so that there is no home, which is as much as $62.8 \%$.

Regarding parental knowledge about drug abuse rehabilitation in adolescents in DKI Jakarta, it is seen that more than half of parents' knowledge is categorized as less (57.1\%). The lack of knowledge is that parents do not know how to carry out the rehabilitation process of adolescent drug abusers by increasing vigilance, providing education on early age drug abuse, and building self-warning to adolescents. The results showed that the attitudes of respondents (parents) toward the rehabilitation of drug abusers in adolescents in DKI Jakarta were more than half less categorized (54.2\%). The attitude of parents in the rehabilitation of adolescent drug abusers is that parents respond to stimulation or objects (information with media images) in the rehabilitation of adolescent drug abusers. Judging from the perception, the results of the study showed that the perception of parents about the rehabilitation of adolescent drug abusers in DKI Jakarta was more than half less categorized (60\%).

Table 1: Frequency distribution of family characteristics of adolescent drug abusers in DKI Jakarta 2017-2018

\begin{tabular}{llll}
\hline Variable & Category & F & $\%$ \\
\hline Behavior & Poor & 21 & 60 \\
& Good & 14 & 40 \\
Mother's age & Old adult & 17 & 48,5 \\
& Young adult & 18 & 51,5 \\
Mother's education & Low (primary school and junior high school) & 15 & 42,8 \\
& High (Zsenior high school) & 20 & 57,1 \\
Mother's profession & Not Work & 13 & 37,2 \\
& Work & 22 & 62,8 \\
Knowledge & Poor & 20 & 57,1 \\
Parents & Good & 15 & 42,9 \\
Attitude & Poor & 19 & 54,2 \\
& Good & 16 & 45.8 \\
Perception & Poor & 21 & 60 \\
& Good & 14 & 40 \\
Parenting & Permissive and authoritarian & 16 & 45,8 \\
& Democratic & 19 & 54,2 \\
\hline
\end{tabular}

Based on the pattern of parenting parents have, the results of the study show that the pattern of parenting for more than half is categorized as democratic $(54.2 \%)$. The right parenting in a family to shape adolescent's character is democratic parenting, which can prioritize the interests of adolescents, but the family must still be able to control them, parenting democracy will form the type of parents who are more rational, realistic, and warm toward family members, so they can make family members comfortable and form a better, stronger, and more polite character in adolescents, Figure 1.

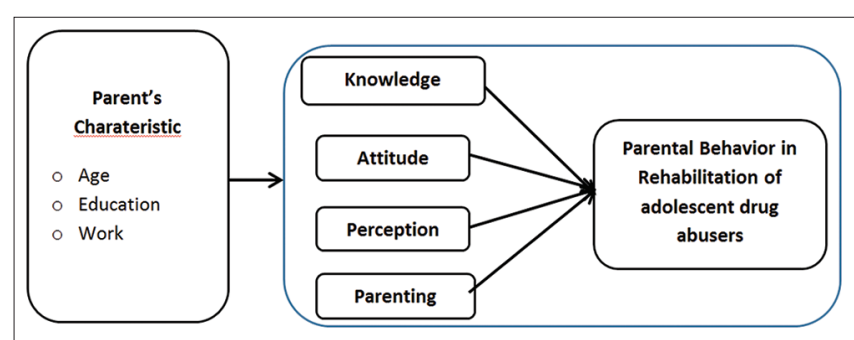

Figure 1: EVIE rehabilitation model 


\section{Discussion}

The problem of drugs in Indonesia is still something that is urgent and complex. In the past decade, this problem has become widespread and evidenced by the increasing number of drug abusers or addicts significantly, along with the increased disclosure of drug crime cases which are increasingly diverse in patterns and increasingly massive in all syndicate networks. Indonesian society, even the world community, in general, is currently faced with a very alarming situation due to the rampant use of various types of illegal drugs. This condition is increasingly worrying due to the rampant illegal circulation of narcotics that has spread in all walks of life, including the younger generation. This greatly affects the life of the nation and country in the future, because the young generation as the next generation of the nation has been contaminated by drugs. This cannot be separated due to the influence of the behavior changes of some teenagers who have significantly ignored the values and norms and laws that apply in the midst of community life. In everyday life, in the midst of society, there are still many teenagers who still do drug abuse.

Families lack closeness with abusing teens. Teenage drug abusers come from families whose parents work outside the home. Moreover, the teenager is not an only child and but also does not have many siblings. This should not be a reason for these teenagers to commit drug abuse.

Parents also said that for several years there were no problems with situations and conditions like those in the family. Parents consider the child no problem and believe in their child.

Teenage drug abuse states that the reason for drug abuse is due to the first because of the lack of supervision from both parents who work to make a living. Second, feeling lonely and lacking family warmth and the third feel friends can be invited to play and can understand their needs.

Drug abuse among adolescents is done because the teens feel "alone," there is nothing to talk to at home because their parents are working and the teen is looking for friends to talk to and who can "click" with him, environmental influences that result in changes in behavior someone so that someone really feels in an environment that is "most familiar" with his needs. Lack of parental supervision and self-awareness of adolescents/self-warning does not make the teenager at risk of abusing drugs.

Drug abuse among students is a serious problem. Three parties are of concern in preventing the spread of drug consumption among students. All three are family environment, learning environment (school), and community environment (neighborhood where people live and socialize). These three environments play their respective roles in the formation of student character.

Creating a drug-free environment for students and students is not an easy matter. Drug abuse that occurs among the younger generation is increasingly widespread. Young people are a potential market for drug dealers. This is also exacerbated because the drive for curiosity and trying new things is also very large among young people. Drug syndicate networks use that vulnerability to make young people a potential market share. The government has a great responsibility to provide information and education about the effects of drug abuse early on.

Ways to save the younger generation from the influence of drugs can be done in various ways. One way to save the younger generation can be done through religious education, healthy relationships, and reinforced with ongoing parental supervision. Parents have an important role in saving young people from drug abuse.

The family must take a big role in killing the need for "vent" for adolescents so that it is not taken by friends who do not necessarily have good intentions. Teenagers will look for environments that they think can meet their needs that they do not get in their immediate environment. More or less, the environment has a role in influencing adolescent behavior in finding their identity. Adolescents in the search for identity will depend on the environment or people nearby to fulfill what they need. Adolescent behavior will depend a lot on the environment that it considers can meet its needs.

Psychological examination in adolescents as victims of drug abuse must be done by a psychologist. Teenage is still a very unstable soul, who is looking for identity and identity. Want to show that he is capable and can do what he wants to know.

The introverted attitude is always closed, and it is difficult to communicate with people who cannot be considered "like" with him, so he will look for friends or groups that he thinks can understand him. If this cannot be taken over by the family, it will be dangerous. Drug abuse cannot be considered normal because it has a long-term impact, for that it needs to be given psychological assistance to heal his soul. One effect is the possibility of recurrence if not handled properly. Teenagers who experience drug abuse experience deep pressure and need a psychological therapy. If not handled properly it will have a long-term impact on its future.

As it is known that, parents have a very important role in parenting, parental behavior in preventing drug abuse in adolescents is a concept of strategic efforts in preventing drug abuse. Knowledge is the most important thing that is needed by the Indonesian people, and it is this lack of knowledge that is causing drug abuse to increase in Indonesia. Not only that, lack of parents' attention to adolescents can also 
cause more and more adolescents to become victims of drug abuse.

The role of family or parents in the rehabilitation of adolescent drug abusers is very important because the role of parents is very large in helping teens to be ready to go to the gates of their lives and the family is the closest person to adolescents, by maximizing their role, a family will become a strong fortress for family members from various bad things that could have arisen from their social environment [6], [7], [8]. Parents should have started applying knowledge about sexuality to their teens, but according to age and the right method and as a parent, you must help them to create a strong personal character for the teenager, because it is a personal provision that can be used later.

Knowledge is proven to be closely related to parental behavior. Parents have a role as educators, because a teenager gets knowledge from his parents, especially his mother and father. Thus, the personality of adolescents is formed due to inheritance from parents and the environment in which adolescents develop because the first environment that gives a profound influence is our own family [9], [10].

Parents who have low knowledge will have a great potential for the occurrence of deviations in parenting toward adolescence because they do not know the impact that might occur, to overcome this, an educational process is needed to socialize parenting that supports democratic values and respects for the rights of adolescents.

Parenting is a pattern of interaction between parents and adolescents, namely, how parents' attitudes or behaviors when interacting with teens, including how to apply rules, teach values/norms, give attention and affection, and show good attitudes and behaviors so that they become role models for adolescents. In this interaction, there is inculcation of values, norms, and rules that apply in society, as well as the development of interests and talents of adolescents. Parenting also means the activities of parents to educate, care for, raise, and meet the needs of adolescents with democratic values but full of responsibility.

Based on the results of the interview, it was concluded that parenting applied by parents of adolescent victims of drug abuse is authoritarian and permissive; the impact of these two parenting forms the character of weak teenagers who are not confident. Authoritarian and permissive parenting tends to be limiting, punishing, and looking at the importance of unconditional obedience [11], [12]. The harshness of parental attitudes makes teens reluctant to tell the problem; this is one of the causes of adolescents to be vulnerable to drug abuse because the attitudes and parenting patterns of parents make adolescents distant or fortify themselves with parents and become a private person.

Prevention does not do right well with prevention education and does not build adolescent independence to prevent drug abuse. This happens because parents still think that giving freedom to adolescents is a democratic thing for the independence of the teenager. Many parents who do not know the benefits of preventive education and develop appropriate self-warnings can prevent drug abuse in adolescents.

Attitude is a reaction or response that is still closed from someone to a stimulus or object. The formation of new behaviors is an attitude starting from the cognitive domain, which means the subject or individual knows in advance the stimulus in the form of material or object so as to cause new knowledge to the individual [13]. Then the increasing knowledge of a person will affect one's attitude. The attitude of parents in dealing with drug abuse is very important. This will have an impact on the risk of drug abuse, especially in adolescents.

Perception is a process due to observations that are initiated by the sensing process, which is the process of receiving a stimulus by the senses, then passed on to the brain, and only then the individual realizes something being perceived. Parents did not expect that family members would commit drug abuse. And in their perception, that the government should overcome the problem of drug abuse. Parents' perception is not entirely true; they still consider their family to be in a safe zone. Families still consider their members, especially their children, "not to" do anything wrong.

The program is not yet maximally, specifically addressing and improving family behavior for the rehabilitation of drug abusers, especially among adolescents, so parents do not fully understand information related to drug abuse. Parents do not fully understand the problem of abuse and how adolescents can do self-warning due to a lack of information on parents in the rehabilitation of adolescent drug abusers. Of course, information related to drug abuse in adolescents can be given to parents to improve the knowledge, attitudes, and perceptions of parents in preventing drug abuse, especially teenagers.

\section{Conclusion}

It can be concluded that adolescent drug abusers the variable power of knowledge and attitudes are the most powerful tool to be used as a family guide in carrying out rehabilitation for adolescent drug abusers to be able to cure and reduce relapse rates on drug abuse among adolescents. A study in a stronger design is needed to look at the impact of these factors in carrying out the rehabilitation process of family-based drug abuse among adolescents.

Efforts in the rehabilitation process to prevent recurrent drug abuse in adolescents are by increasing 
adolescent self-empowerment against the dangers of drug abuse and rehabilitation processes based on family strength. In the formation of self-warning, the role of parents as primary educators is needed so that adolescents become individuals who are not easy to abuse drugs again.

\section{References}

1. Balai Besar Rehabilitasi Badan Narkotika Nasional Indonesia; 2013. https://doi.org/10.21009/jimd.v16i1.1185

2. Wesson DR, Carlin AS, Adams KM, Beschner G. Polydrug Drug Use. New York: Academic Press; 2015.

3. Riskesdas SR. Riset Kesehatan Dasar. Badan Peneltian dan Pengembangan Kesehatan. Jakarta, Indonesia: Kementerian Kesehatan RI; 2018.

4. Tessler RC, Killian LM, Gubman GD. Stages in family response to mental illness: An ideal type. Psychosoc Rehabil J 1987;10(4):3-16. https://doi.org/10.1037/h0099599

5. Dereau C. Pembaru dan Kekuatan Lokal untuk Pembangunan. Indonesia: Australian Community Development and Civil Society Strengthening Scheme; 2013. p. 3.

6. Mallongi A, Natsira MF, Astutia RD, Raufa AU, Rachmatc M, Muhith A. Potential ecological risks of mercury contamination along communities area in tonasa cement industry Pangkep, Indonesia. Enferm Clin. 2020;30:119-22. https://doi. org/10.1016/j.enfcli.2019.10.054

7. Syam A, Sari NP, Thaha AR, Suriah, Jafar N, Salam A, et al. The effect of pumpkin seed flour ( Cucurbita moschata Durch) on zinc serum levels in malnourished Wistar rats. Enferm Clin. 2020;30:337-40. https://doi.org/10.1016/j.enfcli.2019.10.095

8. Mallongi A, Novitasari DA, Noor NB, Fatmawati, Saleh M, Sehalyana, et al. Health risk analysis of phenol and arsenic exposure among kokoda communities village Sorong, West Papua. Enferm Clin. 2020;30:123-6. https://doi.org/10.1016/j. enfcli.2019.10.055

PMid:32545028

9. Loewenson R, Laurell AS, Hogstedt C, D'Ambruoso, Shroff Z. Participatory action research in health systems: A methods reader. The regional network for equity in health in east and Southern Africa. Canada: World Health Organization and the International Development Research Centre; 2014.

10. Fauzan, Nur R, Masni, Mallongi A, Sridani NW, Devi R. Factors related to quality of life of elderly victims of natural disasters in Palu City. Enferm Clin. 2020;30:178-81.

PMid:32545042

11. Paul R. Upaya Penanggulangan Penyalahgunaan Narkoba Oleh Kepolisian. (studi kasus satuan narkoba polres metro bekasi). J Kriminol Indones. 2010;6:232-45.

12. Santrock JW. Child Development. $11^{\text {th }}$ ed. Boston: McGraw-Hill; 2007.

13. Notoatmodjo S. IImu Perilaku Kesehatan. Jakarta: Rineka Cipta; 2010. 